\title{
THE CRITICAL MONOSOMIC SEGMENT INVOLVED IN $4 p$ - SYNDROME: A HIGH-RESOLUTION BANDING STUDY ON FIVE INHERITED CASES
}

\author{
Kouji Narahara, ${ }^{1}$ Yusuke Himoto, ${ }^{2}$ Yuji Yokoyama, ${ }^{2}$ Ryozo Kasal, ${ }^{3}$ \\ Akira Hata, ${ }^{4}$ Kiyoshi KikKawa, ${ }^{1}$ Yukio TaKahashi, ${ }^{1}$ \\ Yoshiharu Wakita, ${ }^{1}$ Shunsuke KimUra, ${ }^{1}$ \\ and Hiroshi Kımoro ${ }^{1}$ \\ ${ }^{1}$ Department of Pediatrics, Okayama University School of Medicine, Okayama 700, Japan \\ ${ }^{2}$ Department of Pediatrics, Fukuyama Citizen's Hospital, Fukuyama 720, Japan \\ ${ }^{3}$ Asahigawa Jidoin Children's Hospital, Okayama 703, Japan \\ ${ }^{4}$ Department of Pediatrics, Okayama National Hospital, Okayama 700, Japan
}

\begin{abstract}
Summary In an attempt to determine the critical monosomic segment involved in $4 p-$ syndrome, we studied the precise breakpoints of five inherited cases with the syndrome using a high-resolution banding technique. The 5 patients ranged in age at diagnosis from newborn to 15 months, 4 of whom could be clinically diagnosed as having $4 p-$ syndrome. Common clinical features included mental retardation, low birth weight, growth failure, hypotonia, microcephaly, peculiar facial dysmorphia and ear malformations. Karyotypes of the 5 were $46, \mathrm{XX},-4,+\operatorname{der}(4), \mathrm{t}(4 ; 21)$ (p16.1;q22.3)pat; 46,XX,-4, +der(4), inv ins(4;9)(p15.32p16.3;q34.3)pat; $46, X X, r e c(4)$, del p,inv(4)(p15.2q35)pat; and $46, X X,-4,+\operatorname{der}(4), t(4 ; 18)$ (p15.2; 11.21)mat (two cases, related). The results suggested that monosomy for the proximal half of the $4 \mathrm{p} 16$ band is sufficient to express $4 \mathrm{p}-$ syndrome.
\end{abstract}

\section{INTRODUCTION}

The partial deletion of the short arm of chromosome $4(4 \mathrm{p}-)$ has long been established as a clinically recognizable syndrome (Wolf et al., 1965; Hirschhorn et al., 1965; Centerwall et al., 1975). Up to the present, more than 120 cases have been documented (Lurie et al., 1980). The majority of those had a de novo deletion (simple deletions, unbalanced translocations involving $4 p$ or ring chromosomes 4 ), but a small proportion of those were the results of parental chromosome aberrations. Although no exact breakpoints were given in most of those cases, it has been suggested that monosomy for the $4 \mathrm{p} 16$ band is responsible for the main clinical 
features of 4p - syndrome (Lejeune et al., 1975; Fryns et al., 1979; Wilson et al., 1981).

The development of high-resolution banding techniques has provided a more precise identification of chromosome abnormalities (Yunis, 1976). The purpose of this paper is to present clinical and cytogenetic findings from five inherited cases with $4 \mathrm{p}-$ syndrome. High-resolution banding studies in these cases indicated that the critical monosomic segment involved in $4 p-$ syndrome lies in the proximal half of the 4p16 band.

\section{CASE REPORT}

The subjects consisted of 5 female infants, ranging in age at diagnosis from newborn to 15 months (Fig. 1). They all were born as the first child to healthy nonconsanguineous parents. The pregnancies were uneventful in all cases, and there was neonatal asphyxia in two cases (cases 1 and 4). Family history for spontaneous abortions and congenital malformations was present in cases 4 and 5 . Pedigree studies showed that these two cases were of the same ancestral origin (Fig. 2). The other cases were unrelated. Clinical findings of the 5 cases were summarized in Table 1. Despite the full-term delivery, their birth weights were inappropriately low (from $1,400 \mathrm{~g}$ to $2,360 \mathrm{~g}$ ). All cases but one (case 5) were clinically suspected as having $4 \mathrm{p}$ - syndrome before the chromosome identification. The clinical diagnosis of case 5 was not feasible, since the coexistence of microphth-
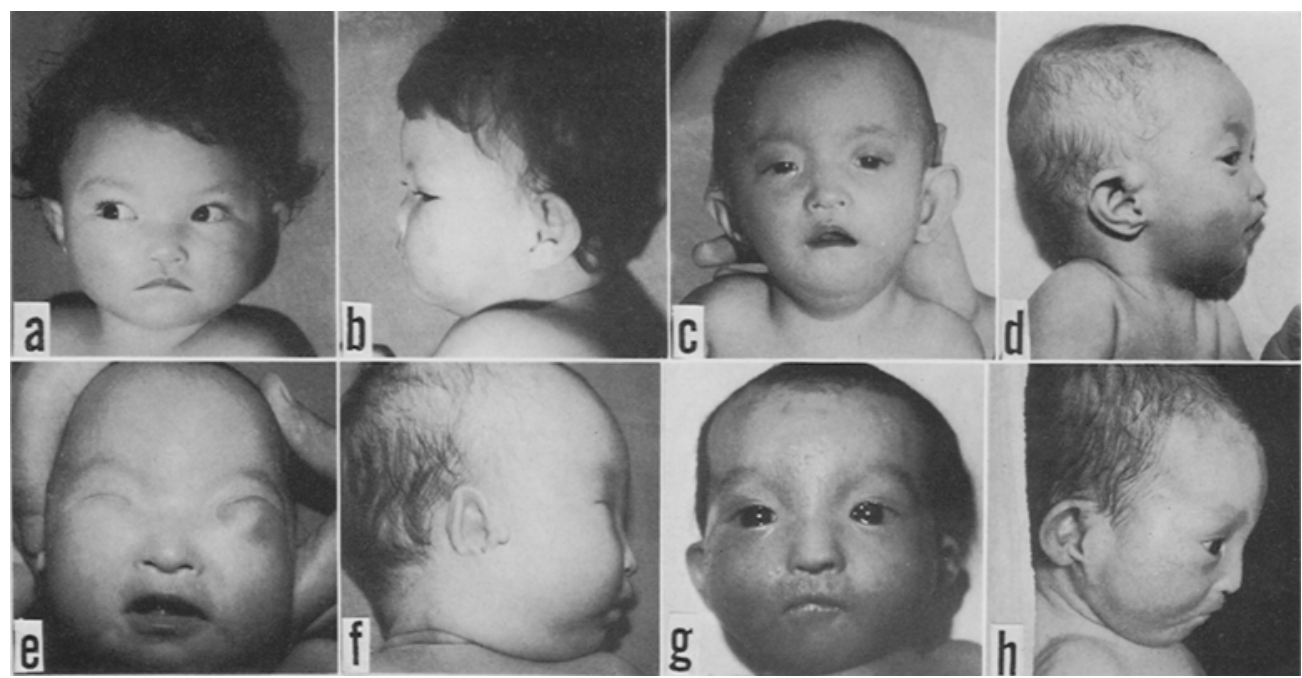

Fig. 1. Frontal and lateral views of the patients: case 1 ( $a$ and b), case 2 (c and d), case 4 (e and $f$ ) and case 5 ( $g$ and $h$ ). No photograph of case 3 was available. 


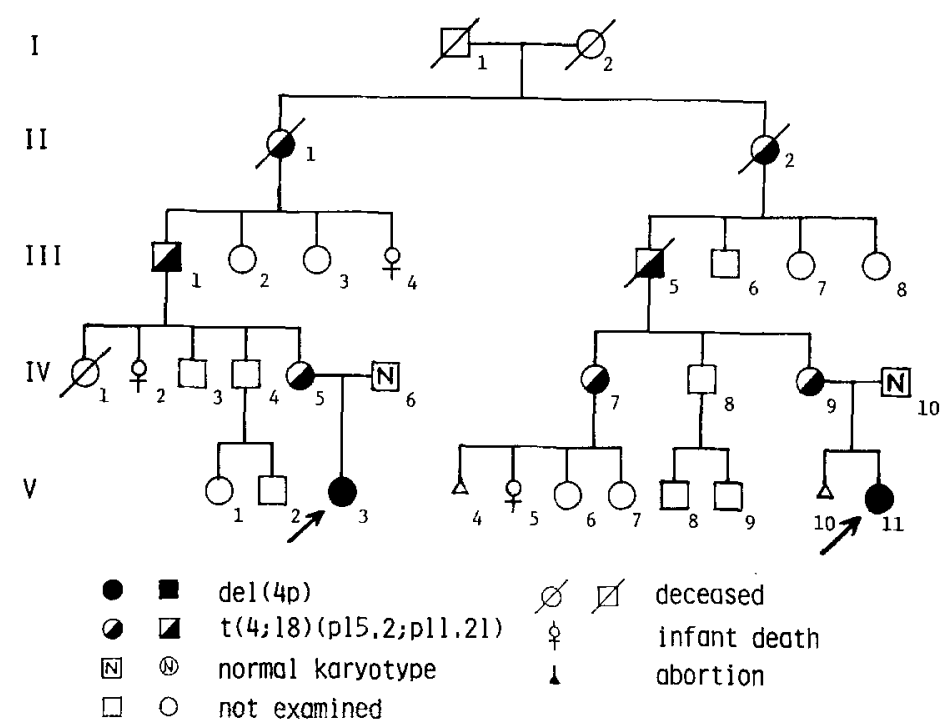

Fig. 2. Family pedigree of cases $4(\mathrm{~V}-3)$ and $5(\mathrm{~V}-11)$. Three decreased individuals (II-1, II-2 and III-5) were considered to be a obligate carrier of the balanced translocation.

almia, gross cavernous hemangioma of the eyelid and hypoplastic auricles obscured the characteristic phenotype of $4 p$ - syndrome. Clinical features shared by the 5 cases were low birth weight, delayed psychomotor development, growth failure, marked hypotonia, microcephaly, low-set and simply formed ears, frontal bossing, prominent glabella, arched eyebrows, hypertelorism, and downturned corners of the mouth. In contrast to the report by Centerwall et al. (1975), broad or beaked nose was found less often. Additional malformations frequently seen in the subjects included prominent bulbi and epicanthic folds (4 cases), micrognathia (4 cases), short philtrum ( 3 cases), strabismus ( 3 cases), congenital heart disease ( 3 cases), obstruction of the nasolacrimal duct ( 2 cases), pes equinovarus ( 2 cases), hemangioma ( 2 cases), and cleft lip and/or palate ( 2 cases). Furthermore, intractable epileptic seizures were noticed in 3 cases: psychomotor seizures in case 1 and grand mal seizures in cases 2 and 5. Computerized tomography of the head and examinations of acoustic brain stem response demonstrated severe brain atrophy and sensorineural deafness in cases 1 and 2 . The complete dermatoglyphic study was available only in case 1. The dermatoglyphics in the remaining cases were difficult to analyze because of the ridge hypoplasia and dissociation. Digital patterns of case 1 were W.W.UL.UL.UL on the right hand and W.W.UL.W.UL on the left, and a total finger ridge count was 88 . There was a simian crease on the right palm and a Sydney line on the left. The main line formula were 11.10.8.3- $\mathrm{t}^{\prime}-\mathrm{L}^{\mathrm{r}} / \mathrm{A}^{\mathrm{r}}$.O.O.L $\mathrm{L}^{\mathrm{d}}$.O on the right palm and 9.7.5".1- $\mathrm{t}^{\prime}-\mathrm{A}^{\mathrm{u}}$.O.O.O. $\mathrm{L}^{\mathrm{d}}$ on the left. With regard to the life prognosis, four out of the 5 cases were alive ( 4 to 22 months old when last seen). 
Table 1. Clinical findings in the 5 patients with $4 \mathrm{p}-$ syndrome.

\begin{tabular}{|c|c|c|c|c|c|c|}
\hline & Case 1 & Case 2 & Case 3 & Case 4 & Case 5 & $\begin{array}{l}\text { Centerwall } \\
\text { et al., } 1975\end{array}$ \\
\hline Sex & $\mathrm{F}$ & $\mathrm{F}$ & $\mathbf{F}$ & $\mathrm{F}$ & $F$ & \\
\hline Age at diagnosis & $15 \mathrm{~m}$ & $7 \mathrm{~m}$ & Newborn & Newborn & Newborn & \\
\hline Parental karyotype & $t(4 ; 21)$ pat & ins(4;9)pat & inv(4)pat & $\mathfrak{t}(4 ; 18)$ mat & $\mathfrak{t}(4 ; 18)$ mat & \\
\hline Maternal age at birth & 27 & 23 & 22 & 21 & 25 & \\
\hline Paternal age at birth & 27 & 28 & 25 & 27 & 26 & \\
\hline Gestational age & $42 w$ & $39 w$ & $39 w$ & $42 w$ & $40 w$ & \\
\hline Birth weight & $2,360 \mathrm{~g}$ & $1,400 \mathrm{~g}$ & $1,635 \mathrm{~g}$ & $1,770 \mathrm{~g}$ & $1,815 \mathrm{~g}$ & \\
\hline Mental retardation & + & + & + & + & + & $50-100 \%$ \\
\hline Growth failure & + & + & + & + & + & $50-100 \%$ \\
\hline Epileptic seizures & + & + & - & - & + & $50-100 \%$ \\
\hline Hypotonia & + & + & + & + & + & $50-100 \%$ \\
\hline Microcephaly & + & + & + & + & + & $50-100 \%$ \\
\hline Frontal bossing & + & + & + & + & + & \\
\hline Prominent glabell a & + & + & + & + & + & $50-100 \%$ \\
\hline Arched eyebrows & + & + & + & + & + & \\
\hline Hypertelorism & + & + & + & + & + & $50-100 \%$ \\
\hline Prominent bulbi & + & + & + & + & $\begin{array}{l}\text { microph- } \\
\text { thalmia }\end{array}$ & \\
\hline Epicanthic folds & - & + & + & + & + & $50-100 \%$ \\
\hline Strabismus & + & + & - & + & - & $50-100 \%$ \\
\hline $\begin{array}{l}\text { Obstruction of the } \\
\text { nasolacrimal duct }\end{array}$ & - & - & + & + & - & $10-50 \%$ \\
\hline Broad or beaked nose & - & + & - & + & - & $50-100 \%$ \\
\hline Short philtrum & + & + & - & + & - & $10-50 \%$ \\
\hline Downslanting mouth & + & + & + & + & + & $50-100 \%$ \\
\hline Cleft lip or palate & - & - & + & + & - & $50-100 \%$ \\
\hline Micrognathia & - & + & + & + & + & $50-100 \%$ \\
\hline Low-set ears & + & + & + & + & + & $50-100 \%$ \\
\hline Simply formed ears & + & + & + & + & + & $50-100 \%$ \\
\hline Preauricular tags & - & - & + & - & + & $10-50 \%$ \\
\hline Accessory ribs & - & - & - & + & 一 & $<10 \%$ \\
\hline Hip dislocation & - & + & - & - & - & \\
\hline Pes equinovarus & + & - & + & - & - & $<10 \%$ \\
\hline Sacral sinus or dimple & - & - & + & + & - & $10-50 \%$ \\
\hline Hemangioma & - & - & + & - & + & $10-50 \%$ \\
\hline Congenital heart disease & $\mathrm{ASD}+\mathrm{PS}$ & - & VSD? & VSD & - & $10-50 \%$ \\
\hline Deafness & + & + & $?$ & $?$ & $?$ & $<10 \%$ \\
\hline
\end{tabular}


Case 3 died from aspiration pneumonia at 3 months of age. The surviving cases showed severe failure to thrive, and two cases (cases 4 and 5) still underwent tube feedings.

\section{CYTOGENETIC STUDIES}

Peripheral blood lymphocytes were cultured using Eagle's minimum essential medium supplemented with $15 \%$ fetal calf serum and phytohemagglutinin. Cells in prometaphase or prophase were collected according to the method of Ikeuchi and Sasaki (1979). Briefly, ethidium bromide $(10 \mu \mathrm{g} / \mathrm{ml})$ and Colcemid $(0.03 \mu \mathrm{g} / \mathrm{ml})$ were added to the culture flasks two hours prior to harvest. Chromosome preparations were aged for one week and then processed by GTG banding. In 4 of the 5 cases, high-resolution banding analysis was successful at the level of more than 550 bands in a haploid set (ISCN, 1981).

Case 1. Although repeated conventional chromosome examinations failed to detect any cytological abnormalities, the high-resolution banding technique showed a subtle deletion involving the 4 p16 band (Fig. 3a). The mother had normal chromosome, while the father was found to have a balanced translocation between chromosomes 4 and 21 (Fig. 3b). The breakpoints were at 4 p16.1 and 21q22.3. The patient's karyotype was $46, \mathrm{XX},-4,+\operatorname{der}(4), \mathrm{t}(4 ; 21)(\mathrm{p} 16.1 ; \mathrm{q} 22.3)$ pat.

Case 2. Chromosome analysis of this patient in other Jaboratory was normal. High-resolution banding, however, disclosed the presence of an interstitial deletion of $4 p$ (Fig. 4a). The father was found to have an inverted insertion of the segment

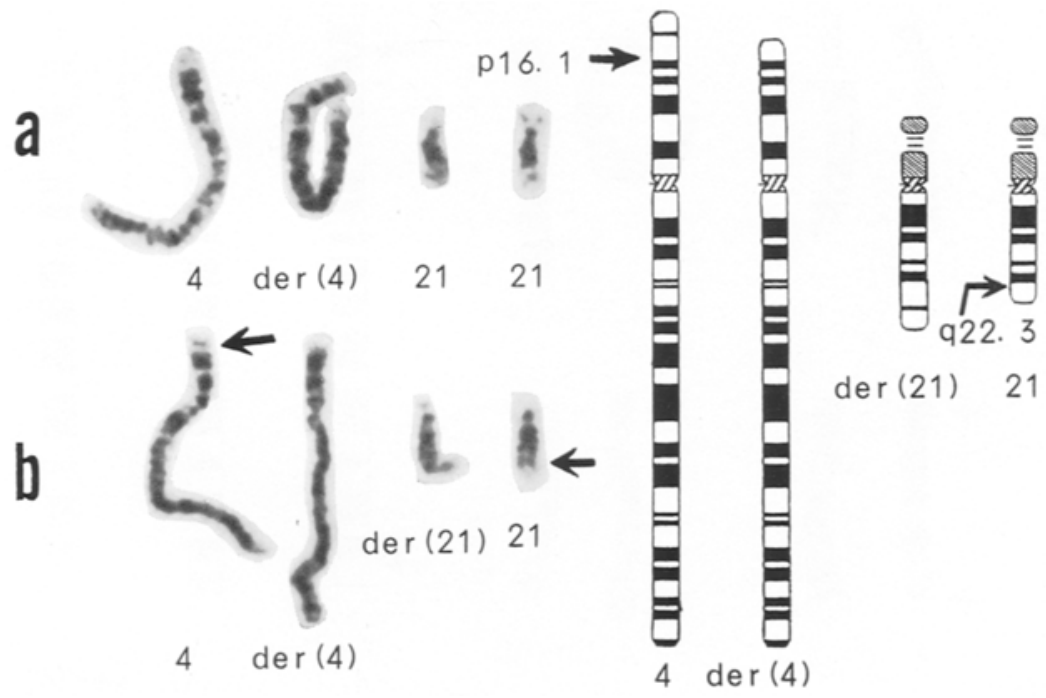

Fig. 3. Partial karyotypes of case 1 (a) and the father (b). Arrows indicate breakpoints. 
4 p15.32 $\rightarrow$ p16.3 into the 9 q34.3 (Fig. 4 b). The patient's karyotype was $46, X X,-4$, $+\operatorname{der}(4)$,inv ins(4;9)(p15.32p16.3; 34.3$)$ pat. The mother had a normal karyotype.

Case 3. In this patient, high-resolution banding analysis was unsuccessful, The conventional chromosome study showed that the short arm of one chromosome

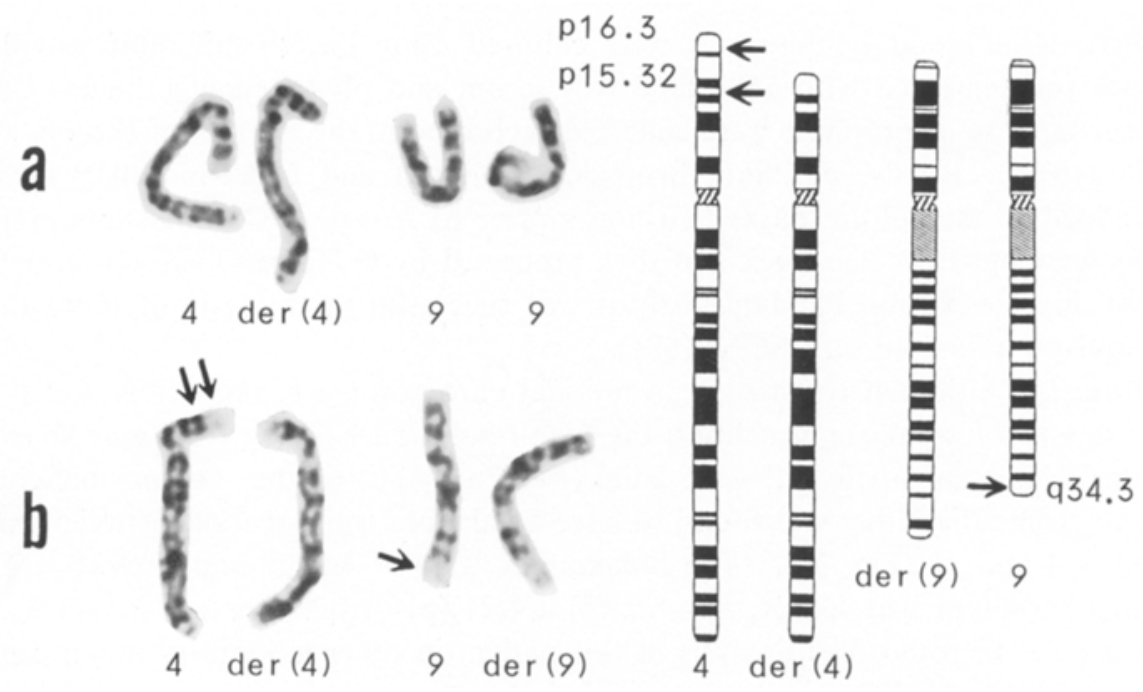

Fig. 4. Partial karyotypes of case 2 (a) and the father (b). Arrows indicate breakpoints.
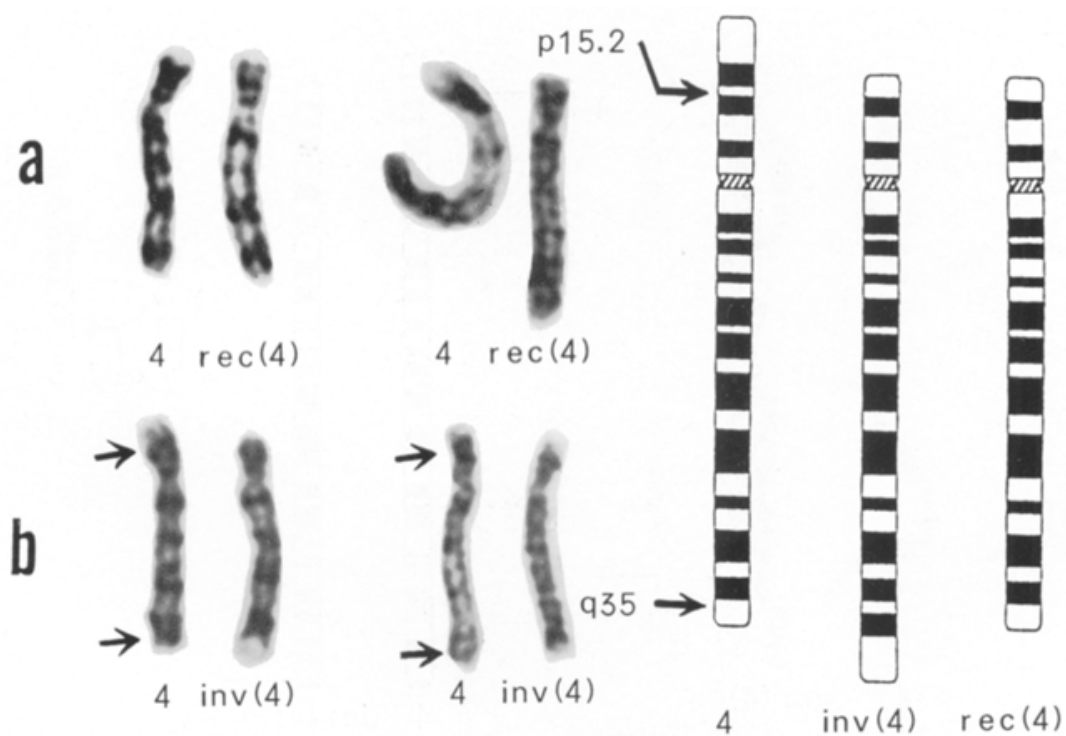

Fig. 5. Partial karyotypes of case 3 (a) and the father (b). Arrows indicate breakpoints. 


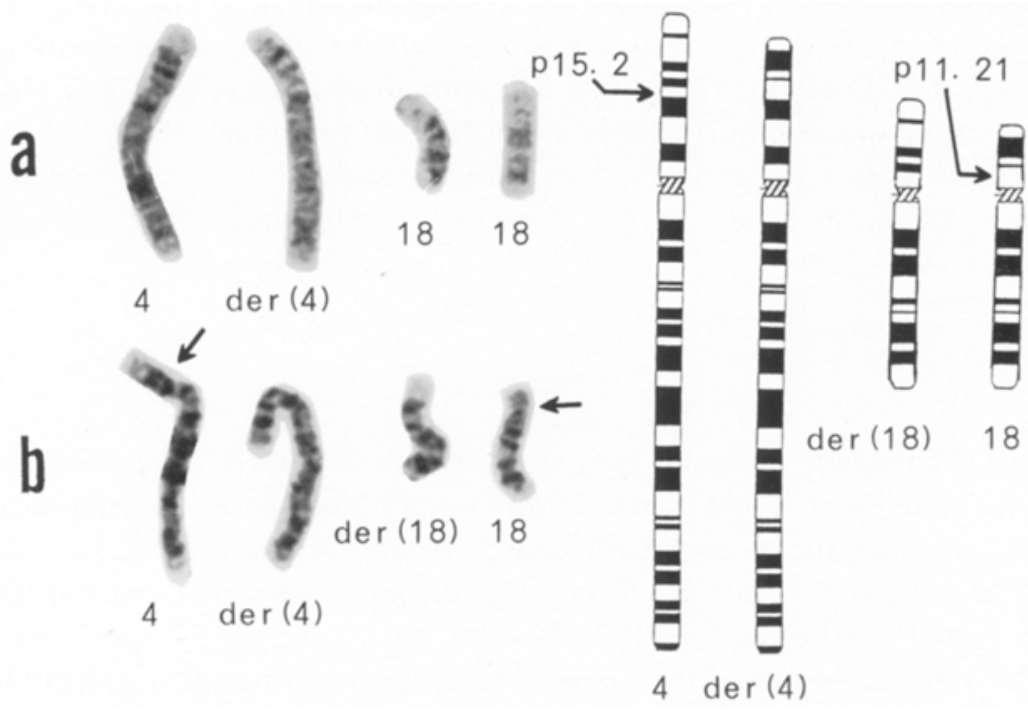

Fig. 6. Partial karyotypes of case 4 (a) and the mother (b). Arrows indicate breakpoints.

4 was shorter than that of the homologue (Fig. 5a). The father was found to be a carrier of a pericentric inversion of chromosome 4 , in which the breakpoints appeared to occur at 4p15.2 and 4q35 (Fig. 5b). The deletion in the patient was considered to result from aneusomic recombination between the inverted chromosome 4 and the normal homologue during meiosis I of the father. The mother had a normal karyotype. The patient's karyotype was 46,XX,rec(4), del p,inv(4)(pI 5.2 q35)pat. Five months after the patient's death, the mother became pregnant. Prenatal diagnosis at 18 weeks' gestation demonstrated that the fetus had the same inverted chromosome 4 as did the father. The pregnancy was elected to continue, resulting in the delivery of a phenotypically normal boy infant.

Cases 4 and 5. The two patients initially seemed unrelated. Pedigree analysis, however, revealed that the two were really related. Both cases had the identical deletion of $4 \mathrm{p}$, which resulted from maternal balanced translocations between chromosomes 4 and 18 (Figs. 6a and 6b, there presented only karyotypes of case 4 and the mother). High-resolution banding study showed the breakpoints at $4 \mathrm{p} 15.2$ and 18p11.21. The karyotypes of the patients were $46, X X,-4,+\operatorname{der}(4), \mathrm{t}(4 ; 18)(\mathrm{p} 15.2$; p11.21)mat. In the pedigree (Fig. 2), III-1 and IV-7 were also found to be a carrier of the balanced translocation.

\section{GENE MARKER STUDIES}

Gene dosage studies of superoxide dismutase 1 (SOD 1) and adenylate kinase 1 (AK 1) were carried out in cases 1 and 2, respectively. SOD of red blood cells 
was measured according to the method of Winterbourn et al., 1975, while AK of red blood cells was assayed with the technique of Beutler (1975). Case 1 was shown to have a normal SOD activity $(3,534 \mathrm{U} / \mathrm{g} \mathrm{Hb}$, normal value $3,434 \pm 486 \mathrm{U} / \mathrm{g} \mathrm{Hb})$. AK activity in case 2 was also normal (192.4 U/g Hb, normal value $232.6 \pm 42.1 \mathrm{U} / \mathrm{g} \mathrm{Hb}$ ). As SOD 1 has been mapped to the band 21q22.1 and AK 1 to $9 \mathrm{q} 34$ (Human Gene Mapping 7, 1984), the results were in line with our cytogenetic interpretations of the two cases.

\section{DISCUSSION}

All of the patients described here showed typical features of $4 p-$ syndrome in spite of the differences in the second chromosomes involved in the translocation or inversion. In the patients except for case 2, monosomy $4 p$ is accompanied by trisomy for a part of the second chromosome being translocated onto $4 \mathrm{p}$ or being inverted: case 1 is trisomic for $21 \mathrm{q} 22.3 \rightarrow$ qter, case 3 for $4 \mathrm{q} 35 \rightarrow$ qter, and cases 4 and 5 for $18 \mathrm{p} 11.21 \rightarrow$ pter. It is conceivable that the trisomic segments in these cases are too short to produce any specific phenotypic abnormalities. Of particular interest, however, is some discordance between the phenotypes of cases 4 and 5, of which karyotypes are wholly identical. The phenotype of case 4 is essentially of $4 p$ - syndrome, whereas that of case 5 is complicated by the presence of microphthalmia, a feature never described in the previous cases with $4 p$ - syndrome. This leads us to assume that 'epistasis' of monosomy 4p over trisomy 18p (Cantú et al., 1981) is involved in the former case but 'phenotypic hybridization' between monosomy $4 \mathrm{p}$ and trisomy $18 \mathrm{p}$ (Stengel-Rutkowski et al., 1984) occurs in the latter case. Which mechanism operates on the phenotypic expression in cases with translocation $4 p$ - syndrome appears to depend for the most part upon the size of the translocated segment of another chromosome. When the translocated segment is long, a 'hybrid phenotype' is likely to take place.

Since the first description of a case with translocation $4 p$ - syndrome by Neu et al., 1975, 16 such cases including ours have been published (Table 2). Second chromosomes involved in the translocations are varied and unspecific. The sex ratio among the translocation cases (females to males $14: 8)$ is similar to that $(2: 1)$ among the de novo deletion cases (de Grouchy and Turleau, 1977). In all cases but two (cases 1 and 12), monosomy $4 p$ occurred as a result of adjacent-1 segregation from parental translocations. Cases 1 and 12 had the apparently same balanced translocations as the mothers. Banding analysis in case 1 substantiated the loss of the 4 p 16 band from the translocated chromosome 1 (Stoll et al., 1981). The occurrence of monosomy $4 \mathrm{p}$ was interpreted by the author as a consequence of an unequal crossing-over during meiosis in the mother. As far as we know, our case 3 is the second example of a patient with $4 p-$ syndrome resulting from a parental pericentric inversion of chromosome 4 . The first reported case with a recombinant chromosome 4 due to a parental inversion, on the other hand, had gross trisomy for 
$4 \mathrm{q} 25 \rightarrow$ qter in addition to monosomy for $4 \mathrm{p} 14 \rightarrow$ pter (van der Linden et al., 1975).

The previous cases with translocation or de novo $4 \mathrm{p}-$ syndrome in which the breakpoints were identified usually had terminal deletions of the $4 p$ segments (Fig. 7), including p13 $\rightarrow$ pter (a), p14 $\rightarrow$ pter (b), p15.1 $\rightarrow$ pter (c), p15.2 $\rightarrow$ pter (d), p15.3

Table 2. Translocation $4 \mathrm{p}-$ syndrome.

\begin{tabular}{|c|c|c|c|}
\hline Case No. & Sex & Parental karyotypes & References \\
\hline 1 & $\mathrm{~F}$ & $\mathrm{t}(1 ; 4)(\mathrm{q} 11 ; \mathrm{p} 16) \mathrm{mat}$ & Stoll et al.; 1981 \\
\hline 2 & $\mathbf{M}$ & $\mathrm{t}(1 ; 4)(\mathrm{q} 42 ; \mathrm{p} 14) \mathrm{pat}$ & Wilson et al., 1981 \\
\hline 3 & $2 \mathrm{~F}$ & $\mathrm{t}(2 ; 4)(\mathrm{q} 37 ; \mathrm{p} 14) \mathrm{mat}$ & Ohdo et al., 1976 \\
\hline 4 & $\mathbf{M}$ & $\mathrm{t}(4 ; 8)(\mathrm{p} 15.3 ; \mathrm{p} 22) \mathrm{mat}$ & Stengel-Rutkoswki et al., 1984 \\
\hline 5 & $\mathrm{~F}$ & $\mathrm{t}(4 ; 9)(\mathrm{p} 15.1 ; \mathrm{p} 23) \mathrm{mat}$ & Aurias et al., 1978 \\
\hline 6 & $\mathrm{~F}$ & $\operatorname{ins}(4 ; 9)(\mathrm{p} 15.2 \mathrm{p} 16.3 ; \mathrm{q} 34.3)$ pat & Present case 2 \\
\hline 7 & F & $\mathrm{t}(4 ; 10)(\mathrm{p} 13 ; \mathrm{q} 26) \mathrm{mat}$ & Hedner et al., 1977 \\
\hline 8 & $\mathbf{M}$ & $\mathrm{t}(4 ; 12)(\mathrm{p} 14 ; \mathrm{p} 13) \mathrm{pat}$ & Mortimer et al., 1978 \\
\hline 9 & $2 \mathrm{~F} 1 \mathrm{M}$ & $\mathrm{t}(4 ; 12)(\mathrm{p} 15.3 ; \mathrm{q} 26) \mathrm{mat}$ & Levy et al., 1976 \\
\hline 10 & $\mathbf{M}$ & $\mathrm{t}(4 ; 18)(\mathrm{p} 16 ; \mathrm{p} 11) \mathrm{mat}$ & Chiyo et al., 1981 \\
\hline 11 & $2 F$ & $\mathrm{t}(4 ; 18)(\mathrm{p} 15.2 ; \mathrm{p} 11.21) \mathrm{mat}$ & Present cases 4 and 5 \\
\hline 12 & $\mathbf{M}$ & $\mathrm{t}(4 ; 19)(? ; ?) \mathrm{mat}$ & Neu et al., 1975 \\
\hline 13 & $\mathrm{~F}$ & $\mathrm{t}(4 ; 20)(\mathrm{p} 15 ; \mathrm{p} 12) \mathrm{pat}$ & Lejeune et al., 1975 \\
\hline 14 & F & $\mathrm{t}(4 ; 21)(\mathrm{p} 16.1 ; \mathrm{q} 22.3)$ pat & Present case 1 \\
\hline 15 & $1 F 1 M$ & $\mathrm{t}(4 ; 22)(\mathrm{p} 15.2 ; \mathrm{p} 11) \mathrm{mat}$ & Lurie et al., 1980 \\
\hline 16 & $1 \mathrm{~F} 1 \mathrm{M}$ & $\mathrm{t}(4 ; 22)(\mathrm{p} 16.1 ; \mathrm{q} 13.33)$ mat or pat & Curry et al., 1982 \\
\hline
\end{tabular}

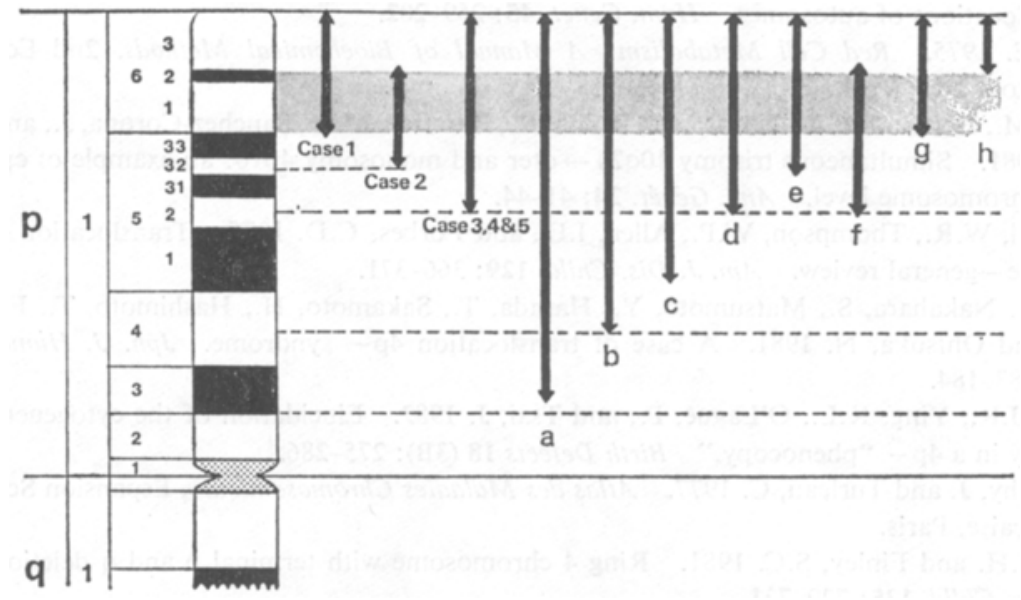

Fig. 7. Schematic representation of deleted segments of $4 p$ in the present and previous cases with 4p- syndrome (see the references of Lurie et al., 1980; Wilson et al., 1981; and Stengel-Rutkowski et al., 1984). The shadowed band represents the critical monosomic segment involved in $4 p$ - syndrome. 
$\rightarrow$ pter $(\mathrm{e})$, pl6.1 $\rightarrow$ pter $(\mathrm{g})$, and p16.3 $\rightarrow$ pter $(\mathrm{h})$. The breakpoint in the last $(\mathrm{h})$ seems questionable, since the translocation of an undetermined chromosome segment onto 4p made the exact identification of the breakpoint difficult (Wilson et al., 1981). An interstitial deletion of $4 p$ as in our case 2 is exceptional, and there has been only one such case (Takata et al., 1983). This case had the breakpoints at $4 \mathrm{p} 15$ and 4 pl6 (f). It is generally acknowledged that the variations in deletions of $4 \mathrm{p}$ do not produce any fundamental phenotypic differences and that the deletion of the terminal 4 p16 band is sufficient to express the main clinical symptoms of $4 p-$ syndrome. The results of the high-resolution banding studies in our subjects, especially in cases 1 and 2, suggest strongly that the critical monosomic segment involved in $4 \mathrm{p}-$ syndrome is within the proximal half of te $4 \mathrm{p} 16$ band. This concept is further supported by the observation that one case with $\mathrm{r}(4)(\mathrm{p} 15 \mathrm{q} 35)$ showed $4 \mathrm{p}$ - syndrome (Fraisse et al., 1977), while another case with $\mathrm{r}(4)$ (p16q35) did not (Finley and Finley, 1981). In the latter case, the deletion did not appear to involve the critical monosomic segment.

The application of the high-resolution banding technique has first made it possible to identify the subtle deletions of $4 p$ in our two cases. There is a possibility that the critical segment is even shorter than the proximal half of the $4 \mathrm{p} 16$ band. This provides an important clinical implication that the extensive cytogenetic investigation using a high-resolution banding technique is warranted for diagnosis and genetic counseling of a case with a 'phenocopy' of $4 p$ - syndrome.

\section{REFERENCES}

Aurias, A., Prieur, M., Dutrillaux, B., and Lejeune, J. 1978. Systematic analysis of 95 reciprocal translocations of autosomes. Hum. Genet. 45: 259-282.

Beutler, E. 1975. Red Cell Metabolism: A Manual of Biochemical Methods, 2nd Ed., Grune Stratton, New York.

Cantú, J.M., Hernandez, A., Nazara, Z., Rolon, R., Ramirez, M.L., Sanchez-Corona, J., and Rivera, H. 1981. Simultaneous trisomy 10q24 $\rightarrow$ qter and monosomy 4p16: an example of epistasis at the chromosome level. Ann. Génét. 24: 41-44.

Centerwall, W.R., Thompson, W.P., Allen, I.E., and Forbes, C.D. 1975. Translocation 4p - syndrome-general review, Am. J. Dis. Child. 129: 366-371.

Chiyo, H., Nakahara, S., Matsumoto, Y., Harada, T., Sakamoto, H., Hashimoto, T., Furuyama, J., and Ohtsuka, N. 1981. A case of translocation 4p- syndrome. Jpn. J. Human Genet. 26: $183-184$

Curry, C.J.R.; Ying, K.L., O'Lague, P., and Tsai, J. 1982. Elucidation of the cytogenetic abnormality in a 4p- "phenocopy." Birth Defects 18 (3B): 275-286.

De Grouchy, J. and Turleau, C. 1977. Atlas des Maladies Chromosomiques, Espansion Scientifique Française, Paris.

Finley, W.H. and Finley, S.C. 1981. Ring 4 chromosome with terminal p and q deletions. Am. J. Dis. Child. 135: 729-731.

Fraisse, J., Lauras, B., Couturier, J., and Freycon, F. 1977. Anneau du chromosome 4. I: avec phenotype 4p-. Ann. Génét. 20: 101-104.

Fryns, J.P., François, B., Timmermans, J., Emmery, L., Speybrouck, J., and van den Berghe, H. 1979. The Wolf-Hirschhorn syndrome. Acta Paediatr. Belg. 32: 135-139. 
Hedner, K., Carlsson, E., and Mitelman, F. 1977. Wolf-Hirschhorn syndrome and balanced (4;10) translocation in the father. Clin. Genet. 12: 101-103.

Hirschhorn, K., Cooper, H.L., and Firchein, I.L. 1965. Deletion of short arms of chromosome 4-5 in a child with defects of midline fusion. Hum. Genet. 1: 479-482.

Human Gene Mapping 7. 1984. Los Angeles Conference (1983). Seventh International Workshop on Human Gene Mapping. Cytogenet. Cell Genet. 37: 1.

Ikeuchi, T. and Sasaki, M. 1979. Accumulation of early mitotic cells in ethidium bromide-treated human lymphocytes cultures. Proc. Jpn. Acad. 55: 15-18.

ISCN. 1981. An international system for human cytogenetic nomenclature-high resolution banding. Cytogenet. Cell Genet. 31: 1.

Lejeune, J., Rethoré, M.O., Dutrillaux, B., Lafourcade, J., Cruveiller, J., and Drillon, P. 1975. Syndrome $4 \mathrm{p}-$ par translocation paternelle $\mathrm{t}(4 ; 20)(\mathrm{p} 15 ; \mathrm{p} 12)$. Lyon Méd. 233: 271-274.

Levy, M., Noel, B., and Viola, D. 1976. Wolf's syndrome in twins-translocation in the mother. Acta Genet. Med. Gemellol. 25: 267-271.

Lurie, I.W., Lazjuk, G.I., Ussova, I., Presman, E.B., and Gurevich, D.B. 1980. The Wolf-Hirschhorn syndrome. I. Genetics. Clin. Genet. 17: 375-385.

Mortimer, J.G., Chewing, W., Miethke, P., and Smith, G.F. 1978. Trisomy $4 \mathrm{p}$ and deletion 4pin a family having a translocation $t(4 p-; 12 p+)$. Hum. Hered. 28: 132-141.

Neu, R., Shott, R.J., and Gardner, L.I. 1975. $4 \mathrm{p}-$ phenotype in an infant with $\mathrm{t}(4 \mathrm{p}-; 19 \mathrm{p}$ or $\mathrm{q}+$ )mat translocation. Am. J. Dis. Child. 129: 363-365.

Ohdo, S., Ikeda, T., and Ogata, H. 1976. Cytogenetic studies of a case of $4 \mathrm{p}-$ syndrome and her mother with balanced translocation, 46,XX,t(2;4)(q37;p14). Acta Med. Univ. Kagoshima 18: $1-8$.

Stengel-Rutkowski, S., Warkotsch, A., Schimanek, P., and Stene, J. 1984. Familial Wolf's syndrome with a hidden $4 p$ deletion by translocation of an $8 p$ segment. Unbalanced inheritance from a maternal translocation $(4 ; 8)(\mathrm{p} 15.3 ; \mathrm{p} 22)$. Case report, review and risk estimates. Clin. Genet. 25: 500-521.

Stoll, C., Pennerath, A., and Lausecker, Ch. 1981. $4 \mathrm{p}-$ syndrome in a girl with translocation $\mathrm{t}(1 ; 4)$ (q11;p16)mat. Hum. Genet. 56: 413-415.

Takata, M., Akamatsu, H., Kashima, M., Shinohara, T., and Takemura, T. 1983. A case of 4psyndrome with disseminated intravascular coagulation: pathological anatomy. Cong. Anom. (in Japanse) 23: 364-365.

Van der Linden, A.G.J.M., Pearson, P.L., and van den Kamp, J.J.P. 1975. Cytological assessment of meiotic exchange in a human male with a pericentric inversion of chromosome No. 4. Cytogenet. Cell Genet. 14: 126-139.

Wilson, M.G., Towner, J.W., Coffin, G.S., Ebbin, A.J., Siris, E., and Brager, P. 1981. Genetic and clinical studies in 13 patients with the Wolf-Hirschhorn syndrome (del $4 \mathrm{p})$. Hum. Genet. 59: 297-307.

Winterbourn, C.C., Hawkins, R.E., Brian, M., and Carrell, R.W. 1975. The estimation of red cell superoxide dismutase activity. J. Lab. Clin. Med. 81: 337-341.

Wolf, U., Reinwein, H., Porsch, R., Schröter, R., and Baitsch, H. 1965. Defizienz an den kurzen Armen eines Chromosomes Nr. 4. Humangenetik 1: 397-413.

Yunis, J.J. 1976. High resolution of human chromosomes. Science 191: 1268-1270. 